\title{
Gebeliğin Tetiklediği Osteomalazi: Olgu Sunumu
}

\author{
Pregnancy-Induced Osteomalasia: Case Report
}

Merih Özgen, Onur Armağan

Eskişehir Üniversitesi Tıp Fakültesi Fiziksel Tıp ve Rehabilitasyon Anabilim Dalı, Eskişehir, Türkiye

\section{Özet}

Gebelik fizyolojik bir süreç olup vücudun tüm sistemlerini etkiler. Gebelik sürecinde ortaya çıkabilen kas iskelet sorunları ağrılı durumlara yol açarak kişinin yaşam kalitesini bozar. Bu olgu gebelik ve takip eden laktasyon süresinde bel ve sırt ağrısı ile başvuran hastalarda osteomalazinin de akılda tutulması gereken patolojilerden biri olduğunu vurgulamak ve literatür eşliğinde tartışmak için sunulmuştur.(Türk Osteoporoz Dergisi 2011;17:93-5)

Anahtar kelimeler: Gebelik, laktasyon, osteomalazi, sırt ağrısı

\section{Summary}

Pregnancy is a physiological process that affects all systems of the body. Musculoskeletal problems can occur during pregnancy and impair the quality of life. This case report is presented to emphasize that osteomalacia should be considered in patients complaining back or low-back pain during pregnancy and lactation period and to discuss in the light of literature. (Turkish Journal of Osteoporosis 2011;17:93-5)

Key words: pregnancy, lactation, osteomalacia, back pain

\section{Giriș}

Gebelik fizyolojik bir süreç olup vücudun tüm sistemlerini etkiler. Sıklıkla etkilenen sistem kas iskelet sistemidir (1). Gebelik sürecinde ligaman laksitesi, postural değişiklikler ve biyomekanik yüklenmenin ağrıya neden olabileceği bilinmektedir (2). Gebelerde bel ve sırt ağrısının gebeliğin erken döneminde başlayarak gebeliğin ilerlemes ile arttığı (\%48-90), doğum sonrasında azalmakla birlikte devam ettiği $(\% 9,4)$ bilinmektedir $(3)$

Nadiren az gelişmiş ülkelerde düşük kalsiyumla beslenen ve çok doğum yapmış kadınlarda osteomalazi vakaları da bildirilmiştir (4). Osteomalazı genellikle D vitaminiyle ilgili yetersiz alım, sentez, absorbsiyon ya da vitamin metabolizmasındaki bozukluklar sonucu ortaya çıkar (5). Bu olgu gebelik ve takip eden laktasyon süresinde bel ve sırt ağrısı ile başvuran hastalarda osteomalazinin de akılda tutulması gereken patolojilerden biri olduğunu vurgulamak ve literatür eşliğinde tartışmak için sunulmuştur.

\section{Olgu}

42 yaşında kadın hasta polikliniğimize sırt ağrısı şikayeti ile başvurdu. Alınan hikayesinde 4 ay önce doğum yaptıktan birkaç hafta sonra sırtında ağıı başladığı, sırt ve bel hareketlerinin oldukça kısıtlandığı, bebeği kucağına almakta ve yatırmakta bile yardıma intiyaç duyduğu, ağrısının geceleri daha fazla olduğu öğrenildi. Vizüel ağrı skalası (VAS) gündüz 7-8, gece 9-10 du. Radiküler ağrı tariflemedi. Tüm gün devam eden tutukluğu vardı. Özgeçmiş sorgulamasında Hemofili C hastası olduğu ve Trombofili (heterozigot Faktör $V$ Leiden ve homozigot MTHFR) nedeniyle gebelik sürecinde ve takibinde toplam 10 ay dalteparin sodyum 5000IU/gün, folik asid 5mg/gün kullandığı öğrenildi. Hasta tüm gebelik süresinde devam eden gastrik şikayetler nedeniyle et, süt ve süt ürünlerini tolere edemediğini, doğumdan sonrada bebekte laktoz intoleransı olduğu için süt ürünlerini alamadığını bildirdi. Ayrıca tüm gebelik süresinde devam eden mide şikayetleri nedeniyle antasit 500mg(4-5adet/gün) kullandığı, düşük tehdidi nedeniyle 4ay süreyle medroksiprogesteron asetat 100mg 2x1/gün kullandığı ve aktivitelerini belirgin şekilde kısıtlandığı öğrenildi. Hastanın sosyokültürel düzeyi iyi ve asri giyim tarzına sahipti. Kas iskelet muayenesinde torakal ve lomber paravertebral kaslarda bilateral spazm, L1 vertebrada belirgin hassasiyet vardı, torakal ve lomber hareketler her yönde ağrıya bağlı kısıtlıydı. Laseque testi bilateral negatifti ve bilateral nörolojik defisit saptanmadı. Çekilen dorsal-lomber grafide aksta düzleşme, L1 ve L2 vertebrada hafif yükseklik kaybı ve osteopenik radyolusens artışı gözlendi. Tam kan sayımı, eritrosit sedimantasyon hızı, C reaktif protein düzeyi, tam

Yazıșma Adresi/Address for Correspondence: Dr. Merih Özgen, Eskișehir Üniversitesi Tıp Fakültesi Fiziksel Tıp Ve Rehabilitasyon Anabilim Dalı, Eskișehir, Türkiye Gsm: +90 5325837099 E-posta: merihsarhus@hotmail.com Gelis Tarihi/Received: 30.10.2011 Kabul Tarihi/Accepted: 22.11.2011 
idrar tetkiki normaldi. Burucella tüp aglitünasyonu testi negatif idi. Biyokimyasal değerleri alkalen fosfataz $381 \mathrm{U} / \mathrm{l}(<240)$ hariç normaldi. Osteopenik görünüm nedeniyle istenen kemik dansitometresinde lomber bölgede en düşük $L 2(T-2,0, Z-1,6)$ olmak üzere total $(T-1,4, Z-1,1)$, kalçada total $(T-2,1, Z-1,8)$ tespit edildi. Vertebral hassasiyet ve yükseklik kaybı nedeniyle istenen manyetik rezonans görüntülemede lomber lordozda düzleşme, açıklığı sağa bakan skolyoz, L1 ve L2 vertebra korpus üst end plaetlerde hafif düzeyli yükseklik kaybı ve kemik ödemi tespit edildi. ALP yüksekliği ve osteopeni nedeniyle istenen parathormon $109 \mathrm{pg} / \mathrm{ml}$ (11-67) idi. Spot idrarda kreatinin 71,53 mg/dl (28217), kalsiyum $2,3 \mathrm{mg} / \mathrm{dl}(6,7-21,3)$ idi. PTH yüksekliği nedeniyle yapılan boyun ultrasonu normaldi. 25-hidroksi vitamin $D<25$ $\mathrm{nmol} / \mathrm{L}$ bulundu. Yapılan tetkik ve değerlendirmeler sonucunda hastaya osteomalazi tanısıyla medikal tedavi olarak altı hafta süreyle, haftada bir vitamin D3 300,000 IU IM, günlük 1000 mg kalsiyum karbonat ve ağrıları için parasetamol 500mg 3X1 verildi. Beslenme, güneşlenme ve egzersiz ile ilgili önerilerde bulunuldu. Hasta iki ay sonra kontrole geldiğinde alkalen fosfataz ve parathormon düzeyi normal sınırlardaydı, 25-hidroksi vitamin D $>125 \mathrm{nmol} / \mathrm{L}$ düzeyine çıkmıştı. Hastanın yakınmaları belirgin şekilde azalmıştı (VAS gündüz ve gece 1-2).

\section{Tartışma}

Osteomalazi; matür veya gelişmekte olan kemikte yetersiz matriks mineralizasyonu sonucu kalsifiye olmamış osteoid miktarının artmasıdır (6). Osteomalazide ağıı ve kas güçsüzlüğü sıklıkla belli belirsiz olması nedeniyle gözden kaçmaya ve yanlış tanıya neden olabilir $(7,8)$. En belirgin klinik özellikler kemikte ağrı ve hassasiyet, iskelette deformite, kas güçsüzlüğü ve hipokalsemi varlığında tetanidir.

Ağrı, vakamızda olduğu gibi osteomalazili hastaların en önde gelen yakınmasıdır. Devamlı ve simetrik olması, yüklenme ile artması tipiktir. Belden başlayıp pelvis, kalça, uyluk, sırt ve kostalara yayılım gösterir. Sternum, spinöz çıkıntılar, pelvis ve kostaların kompresyonunda hassasiyet vardır $(5,8)$. Bizim hastamızda da en önemli bulgu spinöz hassasiyetti. Literatürde periost altındaki demineralize jelatin matriksin hidrasyonu sonucu hidratematriksin, periostu dışa doğru iterek zonklayıcı, künt ağrıya neden olduğu bildirilmiştir (9).

Osteomalazide ilk belirti kırık olabilir. Osteomalazinin tipik radyolojik bulgusu yaygın osteopeni ve psödofraktürlerdir (looser çizgileri) (7). Hastamızın radyolojik olarak incelenmesinde osteopenik görünüm ve vertebralarda yükseklik kaybı vardı fakat radyolojik olarak incelenen alanlarda osteomalaziye özgü olan psödofraktürlere rastlanmadı. Kemik dansitometresinde de osteopeni gösterildi.

Osteomalazi tanısında biyokimyasal testler de yardımcıdır. Serumda kalsiyum, fosfor ve $25(\mathrm{OH}) \mathrm{D} 3$ düzeyleri çoğunlukla düşük, alkalen fosfataz yüksektir. 24 saatlik üriner kalsiyum atılımı azalmıştır. 25(OH)D3 düzeylerinin vücutta vitamin D durumunun en iyi göstergesi olduğu kabul edilir. 25(OH)D3 düzeyinin 20 $\mathrm{ng} / \mathrm{mL}^{\prime}$ nin (50 nmol/L) altında olması D vitamini eksikliği olarak tanımlanır (10). Biyokimyasal bulgular hipokalsemiye ve paratroid cevabın derecesine göre değişir (11). Bizim hastamızda biyokimyasal değerlendirmeler osteomalaziyi destekler nitelikte idi. Mevcut klinik, biyokimyasal ve radyolojik değerlendirmeler eşliğinde hastamıza osteomalazi tanısı konuldu.

Osteomalazi genellikle D vitaminiyle ilgili yetersiz alım veya sentez, absorbsiyon ya da vitamin metabolizmasındaki bozukluk sonucu ortaya çıkar (5). Osteomalaziye bağlı D vitamini eksikliğinin en önemli nedeni güneş ışınlarından mahrum olmaktır. Yaşlılar, koyu tenliler, hamileler ve emziren kadınlar risk grubunu oluşturur (11). Bunun yanında bazı ilaçlar D vitamininin emilimini önler veya metabolizmasını hızlandırarak osteomalaziye yol açabilir(12).

Gebelik sırasında kalsiyum metabolizmasıyla ilgili fizyolojik hormonal değişiklikler gerçekleşir Gebelik süresince gereken ek kalsiyum miktarı 30 g'dır. Gebelik için gereken kalsiyum annedeki depoların \%2,5'a karşılık gelir. Süt ürünlerini yeterince tüketen kadınlarda kalsiyum alımı sağlanmış olur. Hastamızın hamilelikte gastrik şikayetleri ve laktasyon sürecinde bebekteki laktoz intolaransı nedeniyle düşük kalsiyumla beslenme öyküsü mevcuttu. Literatürde nadiren de olsa çok doğum ve gebelik döneminde düşük kalsiyum alımı ile ilişkili osteomalazi vakaları bildirilmiştir $(4,13)$.

Olgumuzda gastrik şikayetleri yüzünden uzun süre alüminyum içeren antasit kullanım öyküsü de mevcuttur. Alüminyum bileşikleri mide asitleri ile etkileşimi sonucu alüminyum klorür oluşturur buda besin kaynaklı fosfatlarla birleşerek fosfatın emilimini engeller. Bu maddelerin uzun süreli kullanımı hipofosfatemiye neden olur. Hipofosfatemi kalsiyumun barsaktan absorbsiyonunda artışa ve kemiklerden mobilizasyonuna neden olur (14). Bu durumun da hastamızda gelişen osteomalazi tablosu ile ilişkili olabileceği düşünülmüştür.

Aynı zamanda hastamızın trombofili nedeniyle yaklaşık on ay düşük moleküler ağırıklı heparin kullanım hikayesi mevcuttur. Heparin ve düşük moleküler ağırlıklı heparinin (enoksaparin, dalteparin, fondaparinux) osteoporoza neden olduğu bilinmektedir (15). Heparin ilişkili kemik kaybı, heparinin üç ay veya daha fazla sürede minimum günlük doz olarak 15000 ünite kullanım sonrası ortaya çıkar. Düşük moleküler ağırlıklı heparinle ilişkili net olmamakla birlikte, literatürde 3 aylık tedavi dozları sonrası vertebra fraktürlerinin ortaya çıktığı bildirilmiştir (16). Biz de hastamızda tespit ettiğimiz vertebral yükseklik kaybının 10 ay süre ile kullandığı düşük moleküler ağırıklı heparin ile ilişkili olduğu kanısındayız.

Hastamızın sosyokültürel düzeyinin iyi olması, asri giyinme tarzına sahip olmasına rağmen gebelik ve laktasyon sürecindeki gastrik şikayetleri nedeniyle beslenmesindeki değişimlere ek olarak osteomalazi ile ilişkili çoklu ilaç kullanımının osteomalazi tablosunun ortaya çıkmasına neden olduğu kanısındayız.

Osteomalazinin tedavisinde amaç fraktür ve kemik ağrısını azaltmaktır. Hastalığın etiyolojisine göre tedavi düzenlenmelidir. Tanı doğru olduğunda tedavi başarılıdır ve semptomlar kısa sürede düzelir. Hastamız bize başvurduğunda osteomalazi tablosuna neden olabilecek ilaç kullanımları sonlanmıştı ve gastrik şikayetleri geçmişti. Bebekteki laktoz intolaransı nedeniyle süt ürünlerini tüketimi hala kısıtlıydı. Eksik D vitaminini yerine koymak için medikal tedavi olarak altı hafta süreyle, haftada bir Vitamin D3 300,000 IU IM, günlük 1000 mg kalsiyum karbonat ve ağrı kontrolü, için parasetamol 500mg $3 \times 1$ verildi. Beslenme, güneşlenme ve egzersiz ile ilgili önerilerde bulunuldu. Osteomalazi tedavi takibinin kalsiyum, fosfor, alkalen fosfataz ve serum $250 \mathrm{HD}$ vit ile yapılması önerilir (11). Bizim hastamızın iki ay sonraki 
kontrolünde alkalen fosfataz, parathormon ve $250 \mathrm{HD}$ vit değerlerinin normal sınırlara ulaştığı gözlendi. Hastanın yakınmalarının kısa sürede düzeldi. Devam tedavisi olarak hastaya günlük 800 IU D vitamini ve 600 mg kalsiyum önerildi.

Hamilelik döneminde D vitamini plesenta aracılığı ile çocuğa geçer, annedeki eksiklik çocukta da Vitamin D eksikliğine neden olur ve bu durum neonatal hipokalsemi olarak kendini gösterir (4). Gebelik döneminde $D$ vitamini eksikliği olan hamilelerin bebeklerinin de risk altında olması nedeniyle osteomalazi aynı zamanda önemli bir halk sağlığı sorunudur. Gebelik tek başına osteomalazi açısından risk oluşturmasa da özellikle vakamızda olduğu gibi ilave risk faktörleri olan bireylerde hem anne hem de bebek sağlığının korunması açısından takip ve önlemlerin alınması gereklidir.

\section{Sonuç}

Osteomalazi genellikle D vitamini yetersizliğine bağlı gelişen bir bozukluktur. Risk föktörleri olan gebelerde, gebelik ve laktasyon bu tablonun ortaya çıkmasında tetikleyici bir rol olabilir. Gebelik ve laktasyon döneminde bel ve sırt ağrısı ile başvuran hastalar, osteomalazi açısından dikkatle değerlendirilmelidir. Bunun yanında gebelik döneminde annedeki D vitamini eksikliğinin bebekte de D vitamini eksikliğine neden olabileceği unutulmamalıdır.

\section{Kaynaklar}

1 Füzün S. Gebelik Rehabilitasyonu. In: Oğuz H. Tıbbi Rehabilitasyon. İstanbul: Nobel Tip Kitapevi, 1995:671-84

2. Moore K, Dumas G.A, Reid J.G.Postural changes associated with pregnancy and their relationship with low-back pain. Clinical Biomechanics. 1990:5:169-174

3. Kristiansson, P, Svärdsudd K, von Schoultz B. Back Pain During Pregnancy: A Prospective Study. Spine 1996;21:702-9
4. Yüzbir N, Şen C. Gebelik ve süt verme döneminde beslenme. Perinatoloji Dergisi 2001;9: 1-9

5. Stamp TCB: Rickest and osteomalacia. Klippel JH, Dieppe PA (Eds): Rheumatologly. Mosby CV, London, 1994; pp 7-35

6. Petifor JM, Daniels ED. Vitamin D deficiency and nutritional rickets in children. In: Feldman D, Glorieux FH, Pike JW (Eds). Vitamin D. San Diego: Academic Press, 1997;663-678

7. Jan de Beur SM, Streeten EA, Civelek AC, McCarthy EF, Uribe L, Marx SJ, Onobrakpeya O, Raisz LG, Watts NB, Sharon M, Levine MA. Localisation of mesenchymal tumours by somatostatin receptor imaging. Lancet 2002;359:761-763

8. Whyte MP, Thakker RV. Rickets and osteomalacia. Bone Disorders 2007:33:70-4

9. Shanna Nesby-O'Dell, Kelley S Scanlon, Mary E Cogswell, Cathleen Gillespie, Bruce W Hollis, Anne C Looker, Chris Allen, Cindy Doughertly, Elaine W Gunter and Barbara A Bowman. Hypovitaminosis D prevalence and deterninants among African American and white women of reproductive age. Third National Health and Nutrition Examination survey, 1988-1994. Am J Clin Nutr 2002;76:187-92.

10. Dawson-Hughes B, Heaney RP, Holick MF, Ips P, Meunier PJ, Vieth R. Estimates of optimal vitamin D status. Osteoporos Int 2005;16:713-6.

11. Uğurlu H. Osteomalazi, Paget Hastalı̆ı. In: Beyazova M, Kutsal YG(Eds). Fizikse tıp ve rehabilitasyon (2.cilt). 2.baskı. Ankara: Güneş Tıp Kitabevleri; 2011. P 2661-267.

12. Bischoff-Ferrari HA, Giovannuci E, Wlliett WC, Dietrich T, DawsonHughes B. Estimation of optimal serum concentration $s$ of 25hydroxyvitamin D for multiple health outcomes. Am J Clin Nutr 2006;84:18-28.

13 Ward AK, Adams JM, Mughal MZ: Bone status during adolesence, pregnancy and lactation. Curr Opin Obstet Gynecol 2005;17:435-39

14. Özdemir O, Topal G, Kayaalp SO.Peptik ülser tedavisinde kullanılan ilaçlar. In:Kayalp SO(Ed). Rasyonel tedavi yönünden tıbbi farmakoloji. 12.baskı. Ankara: Pelikan Kitabevi; 2009. P. 1361-76

15. Lowe $H$, Shane E. Osteoporosis associated with illnesses and medications. In: Marcus R, Feldman D, Nelson DA, Rosen CJ (Eds): Oseoporosis 3rd (Ed).San Diego, California: Elsevier Academic Pres;2008. P. 1283-1314

16. Rajgopal R, Butcher M, Weitz J, Shaughnessy SG. Heparin synergistically enhances interleukin-11 signaling through upregulation of the MAPK patway. J Biol Chem 2006;281:20780-7 